$11-1992$

\title{
Increased Reactive Oxygen Intermediate Production by Hemocytes Withdrawn from Crassostrea virginica Infected with Perkinsus marinus
}

\author{
RS Anderson \\ KY Paynter \\ EM Burreson \\ Virginia Institute of Marine Science
}

Follow this and additional works at: https://scholarworks.wm.edu/vimsarticles

Part of the Aquaculture and Fisheries Commons

\section{Recommended Citation}

Anderson, RS; Paynter, KY; and Burreson, EM, Increased Reactive Oxygen Intermediate Production by Hemocytes Withdrawn from Crassostrea virginica Infected with Perkinsus marinus (1992). Biological Bulletin, 183(3), 476-481.

$10.2307 / 1542024$

This Article is brought to you for free and open access by the Virginia Institute of Marine Science at W\&M ScholarWorks. It has been accepted for inclusion in VIMS Articles by an authorized administrator of W\&M ScholarWorks. For more information, please contact scholarworks@wm.edu. 


\title{
Increased Reactive Oxygen Intermediate Production by Hemocytes Withdrawn from Crassostrea virginica Infected with Perkinsus marinus
}

\author{
ROBERT S. ANDERSON ${ }^{1}$, KENNEDY T. PAYNTER ${ }^{2}$, AND EUGENE M. BURRESON ${ }^{3}$ \\ ${ }^{1}$ Chesapeake Biological Laboratory, University of Maryland System, P. O. Box 38, Solomons, \\ Maryland 20688, ${ }^{2}$ Department of Zoology, University of Maryland, College Park, Maryland 20742, \\ and ${ }^{3}$ Virginia Institute of Marine Science, School of Marine Science, The College \\ of William and Mary, Gloucester Point, Virginia 23062
}

\begin{abstract}
Perkinsus marinus is a protozoan parasite responsible for a major infectious disease of the Eastern oyster, Crassostrea virginica. Nonspecific immunity was assayed in oysters with known intensities of infection so that the physiological responses of the host elicited by the parasite could be better understood. This report describes the capacity of hemocytes to generate reactive oxygen intermediates during the progression of the disease. The hemocytes constitute the major internal defense effector system of oysters, and cytotoxic oxygen species are thought to play central roles in antimicrobial activities of hemocytes and other phagocytic cells. Production of oxyradicals by both resting and phagocytically stimulated hemocytes was quantified by luminol-augmented chemiluminescence. Hemocytes from oysters with heavy Perkinsus infections produced significantly higher levels of chemiluminescence than their counterparts withdrawn from lightly or moderately infected individuals. Furthermore, in addition to a higher chemiluminescent activity per cell, the total circulating hemocyte count was elevated in the heavily infected animals. Therefore, advanced cases of this disease seem to be characterized by hemocytc activation and recruitment, with concomitant exuberant production of hemocyte-derived reactive oxygen intermediates. The resultant oxidant load may participate in the pathogenesis of the disease.
\end{abstract}

Received 1 June 1992; accepted 14 September 1992.

Abbreviations: $\mathrm{CL}=$ chemiluminescence; $\mathrm{CSM}=$ cell supported medium; $\mathrm{MB}=$ Mobjack Bay; $\mathrm{ROI}=$ reactive oxygen intermediates.

\section{Introduction}

Upon appropriate stimulation, phagocytic cells typically undergo a burst of respiratory activity and manufacture large quantities of cytotoxic oxidants. This activity was first reported in mammalian neutrophils and macrophages, but has subsequently been observed in phagocytes from most vertebrates and invertebrates. The details of the production of reactive oxygen intermediates (ROIs) by these cells may be found in reviews by Badwey and Karnovsky (1980), DeChatelet et al. (1982), Klebanoff (1982), Babior (1984), and Babior et al. (1988). Cell-derived ROIs can participate in protective antimicrobial mechanisms and mediate various kinds of host tissue injury. The ultimate source of these oxidants is the superoxide anion $\left(\mathrm{O}_{2}^{-}\right)$produced by the one-electron reduction of oxygen at the expense of NADPH; the reaction is catalyzed by a membrane-bound flavoprotein oxidase. Superoxide undergoes enzymatic dismutation to produce hydrogen peroxide $\left(\mathrm{H}_{2} \mathrm{O}_{2}\right)$, which may give rise to other highly toxic species, such as the hydroxyl radical $(\mathrm{OH})$, via the Fenton reaction, or hydrochlorous acid ( $\mathrm{HOCl})$ via myeloperoxidase. The roles of phagocyte-generated ROIs in the pathogenesis of certain mammalian diseases has gained considerable recent attention (e.g., see Halliwell, 1988; Cerutti et al., 1988) particularly with regard to inflammatory cell damage of the vascular endothelium in atherosclerosis, tissue injury during myocardial ischemia and reperfusion, immune complex-induced acute lung injury, and glomerulonephritis. The health of aquatic organisms may also be effected by oxidative stress (DiGiulio 
et al., 1989). The mechanisms underlying oxidant damage of cells are numerous but are thought to include: decreased ATP levels via inhibition of mitochondrial oxidative phosphorylation, increased DNA strand breaks and other structural and functional alterations of nucleic acids, interference with intracellular enzymes, peroxidation of membrane lipids with concomitant reduction in structural integrity, and various other deleterious interactions with cell membrane proteins and lipids (Fantone and Ward, 1982; Kako, 1987; Cochrane et al., 1988).

As previously noted, the respiratory burst and accompanying production of ROIs are not restricted to mammalian phagocytes. The literature on these activities by molluscan hemocytes has been expanding since the initial report of $\mathrm{H}_{2} \mathrm{O}_{2}$ release from scallop amebocytes by Nakamura et al. (1985). Recently, the hemocytes of many molluscan species have been shown to produce $\mathrm{O}_{2}^{-}$and $\mathrm{H}_{2} \mathrm{O}_{2}$ (Dikkeboom et al., 1987 and 1988; Adema et al., 1991 a; Bachère et al., 199 la; Pipe, 1992), and this activity may be modulated by exposure to certain environmental contaminants (Larson et al., 1989; Fisher et al., 1990; Anderson et al., 1992a, 1992b) or by microbial infection (LeGall et al., 1989, 1991; Hervio et al., 1989). Myeloperoxidase activity has also been measured in bivalve hemocytes (Schlenk et al., 1991). The subject of ROI expression by molluscan phagocytes has been reviewed recently by Adema et al. (1991b).

As is the case for of oxyradicals in other species, molluscan ROIs probably participate in antimicrobial defense, but they also have a destructive potential. The balance between ROI production and activities of protective mechanisms (superoxide dismutase (EC 1.15.1.1), catalase (EC 1.11.1.6), glutathione peroxidase (EC 1.11.1.9), glutathione, vitamins $\mathrm{A}, \mathrm{C}$ and $\mathrm{E}, \beta$ carotene, etc.) is critical in determining the extent of oxidative damage. The contribution of ROIs from activated hemocytes to oxidant loads already present due to normal or pollution-enhanced oxyradical production (reviewed by Livingstone et al., 1989, 1990; Winston et al., 1990; Winston, 1991) could theoretically overwhelm the antioxidant defense mechanisms of mollusks.

In this paper we report that hemocytes from oysters heavily infected with the protozoan parasite Perkinsus marinus produce significantly elevated levels of ROIs; the possibility that this contributes to the pathogenesis of the disease is raised.

\section{Materials and Methods}

\section{Animals}

The oysters (Crassostrea virginica) used in this study were spawned in July 1989 and introduced as spat into an area with low Perkinsus (the Wye River, MD, salinity $\sim$ eight ppt) in September 1989. Two groups from this population were transferred to a high Perkinsus site in Mobjack Bay, VA ( 20 ppt salinity): the first group on 14 April 1991, and the second group on 28 July 1991. Both the Perkinsus prevalence and the higher salinity of Mobjack Bay favored infection and progression of the disease in the transplanted oysters (Paynter and Burreson, 1991). The above transfer protocol was designed to make available oysters with a wide spectrum of disease stages.

Both groups of Mobjack Bay oysters were sampled twice (on 10 and 17 September 1991), held on ice, and transported to the laboratory within $24 \mathrm{~h}$ of collection. They were numbered and housed at ambient temperatures and salinity $\left(23^{\circ} \mathrm{C}, 20 \mathrm{ppt}\right)$ in aerated aquaria. Hemolymph samples were withdrawn from the adductor muscle sinus for chemiluminescence (CL) studies and for hemocyte enumeration; all of the hemolymph samples were collected within three days of receipt of the oysters. The animals were replaced in the aquaria; all specimens living at the end of the hemolymph collection period (three days) were individually diagnosed and staged for Perkinsus by the thioglycollate method (Ray, 1952, 1966).

Oysters that became moribund before they could be diagnosed by the thioglycollate method were fixed in $\mathrm{Da}-$ vidson's AFA and examined by histology. Histological diagnoses have been found to provide slightly lower estimates of infection levels than the thioglycollate method. Based on this experience, the histological diagnoses were adjusted slightly to enable them to be expressed by the thioglycollate scoring method. In this study, 55 diagnoses were carried out via thioglycollate, and 25 were initially performed by histology and converted to thioglycollate scores. To quantify the level of infection in individual oysters, the subjective criteria of light, moderate, and heavy, based on Ray (1952), were given the numeric values of 1,3 , and 5 , respectively.

\section{Reactive oxygen intermediate determination}

The production of ROIs by oyster hemocytes was quantified by measuring luminol-augmented chemiluminescence (CL) before and after phagocytic stimulation. To obtain the hemocytes, several $\mathrm{ml}$ of hemolymph were withdrawn from the adductor muscle sinus via a small notch cut in the edge of the valves. An aliquot was placed on a hemacytometer and the total cell count determined; the remaining hemolymph was further processed for $\mathrm{CL}$ evaluation. The hemolymph was incubated for $15 \mathrm{~min}$ at room temperature in a plastic petri dish, during which time the majority of the cells became firmly attached. Filter-sterilized ambient water from the oyster tanks (FA) was then used to gently wash off the fluid phase of the hemolymph and any unadhered cells. The cell monolayer was then overlaid with FA and incubated for $2.5 \mathrm{~h}$ at room temperature. During this period the cells became 
progressively more loosely attached and could be finally washed free and resuspended in FA. These cells retained phagocytic activity, but showed little of the clumping typically encountered during the centrifugation and resuspension of freshly collected cells. The hemocytes were removed from suspension by centrifugation $(200 \mathrm{~g}, 15$ $\mathrm{min}$ ), resuspended in cell support medium (CSM), and counted. The composition of CSM was $0.5 \%$ antibiotic solution $(10,000 \mathrm{U}$ penicillin, $10 \mathrm{mg}$ streptomycin, and $25 \mu \mathrm{g}$ amphotericin $\mathrm{B} / \mathrm{ml}), 5 \%$ fetal calf serum, and $1 \mathrm{mg} /$ $\mathrm{ml}$ glucose in FA. One $\mathrm{ml}$ aliquots of the hemocyte suspension $\left(10^{6}\right.$ cells in CSM) were placed in small scintillation vials. From this point on, all steps were carried out in a dark room under dim red illumination. To each vial was added $0.3 \mathrm{ml} \mathrm{FA}$ and $1 \mathrm{ml}$ luminol $(250 \mu \mathrm{M}$ in FA), and the vials were placed in a scintillation counter programmed for single photon monitoring. The vials were counted at $0.3 \mathrm{~min}$ intervals for about $10 \mathrm{~min}$ to establish the level of unstimulated, background $C L$ for each sample. Then $0.2 \mathrm{ml}$ of a suspension of heat-killed, washed yeast cells (final particle:hemocyte ratio $=\sim 20: 1$ ) were added to the vials to provide phagocytic stimulation. The vials were counted at $0.3 \mathrm{~min}$ intervals for about $2 \mathrm{~h}$ after the addition of yeast.

Chemiluminescence (counts per min) was recorded directly on computer disks and as printed output from the scintillation counter. The background (basal) CL level was defined as the cpm recorded immediately before the addition of the phagocytic stimulus. The peak $C L$ was the maximal CL response elicited by the phagocytic event (corrected for background). The total $\mathrm{CL}$ response was expressed as the area under the phagocytically induced portion of the curve (estimated by a polygon summation method).

The raw CL data were not normally distributed and were transformed $(\ln [1+\mathrm{X}])$ to permit statistical analysis of variance; multifactor ANOVA was performed as appropriate. Differences between data groups were considered significant if $P<0.05$ (F-test). Post hoc tests (Fisher PLSD and Scheffe F-test) were also run and significance at the $95 \%$ level determined.

\section{Results}

\section{Batch differences}

Two batches of oysters, taken a week apart, were sampled from each of the two transplanted groups in Mobjack Bay. The possibility that the two batches were significantly different from each other with regard to mean levels of $\mathrm{CL}$ activity was investigated. The level of infection showed no significant difference between batches within the groups. The various raw $C L$ parameters showed a trend (batch $1<$ batch 2); after log transformation, the only parameter to show this effect was total CL $(P=0.0298)$.
Table I

Intensities of Perkinsus marinus infection in oyster groups with different residency times in Mobjack Bay (MB)

\begin{tabular}{ccc}
\hline \hline \multicolumn{2}{c}{ Infection level* } & \\
$\begin{array}{c}\text { Group 1 } \\
\left(\begin{array}{c}\text { wks in MB; } \\
\mathrm{n}=39)\end{array}\right.\end{array}$ & $\begin{array}{c}\text { Group 2 } \\
\text { wks in MB; } \\
\mathrm{n}=41)\end{array}$ & $\begin{array}{c}P \text { value } \\
(\text { ln }[1+\mathrm{X}] \text { transformed data; } \\
\text { F-test, one factor ANOVA })\end{array}$ \\
\hline $1.6 \pm 0.2$ & $3.8 \pm 0.3$ & 0.0001 \\
\hline
\end{tabular}

* Each oyster scored for level of infection: $1=$ light. 3 = moderate, 5 $=$ heavy.

Because of the highly significant differences reported below between the two transplanted groups, with regard to all $\mathrm{CL}$ parameters and infection levels, the batch effects were considered minimal, and the data were analyzed by two factor ANOVA using group data and levels of infection.

\section{Group differences}

As outlined in Materials and Methods, the two groups were derived from the same spawning, but differed with regard to the period spent in Mobjack Bay (MB), during which time they were exposed to increased salinity, increased Perkinsus exposure, and other environmental factors present in that location. As expected, the mean level of infection recorded for group $2(\sim 22$ weeks in $\mathrm{MB})$ was higher than that of group 1 ( $\sim 7$ weeks in $\mathrm{MB})$, as seen in Table 1. Table IIa indicates that the background,

\section{Table II}

Luminol-augmented chemiluminescence by $10^{6}$ hemocytes from oysters infected with Perkinsus marinus

a: Hemocytic chemiluminescence (mean cpm \pm SEM) from oyster groups with different intensities of Perkinsus marinus infection.

\begin{tabular}{lccc} 
CL & $\begin{array}{c}\text { Group 1 } \\
\text { Lightly infected } \\
(\mathrm{n}=39)\end{array}$ & $\begin{array}{c}\text { Group 2 } \\
\text { Heavily infected } \\
(\mathrm{n}=41)\end{array}$ & $\begin{array}{c}P \text { value (F-test, two } \\
\text { factor ANOVA, } \\
\text { In }[1+\mathrm{X}] \\
\text { transformed data })\end{array}$ \\
\hline Background & $121 \pm 22$ & $347 \pm 49$ & 0.0294 \\
Peak & $276 \pm 107$ & $1,050 \pm 174$ & 0.0031 \\
Total & $23.632 \pm 9.266$ & $80.720 \pm 13.513$ & 0.0098 \\
\hline
\end{tabular}

b: Hemocytic chemiluminescence (mean cpm \pm SEM) from individual oysters with various levels of $P$. marinus infection.

\begin{tabular}{lcccc} 
& \multicolumn{3}{c}{ Level of infections } & \\
\cline { 2 - 4 } \multicolumn{1}{c}{ CL } & $\begin{array}{c}\text { Light } \\
\text { parameter }\end{array}$ & $\begin{array}{c}\text { Moderate } \\
(\mathrm{n}=38)\end{array}$ & $\begin{array}{c}\text { Heavy } \\
(\mathrm{n}=13)\end{array}$ & $\begin{array}{c}\text { (calculated } \\
\text { as above) }\end{array}$ \\
\hline Background & $128 \pm 20$ & $105 \pm 22$ & $452 \pm 62$ & 0.0115 \\
Peak & $305 \pm 105$ & $253 \pm 85$ & $1,388 \pm 229$ & 0.0036 \\
Total & $24,834 \pm 8,336$ & $18,506 \pm 6,499$ & $108,771 \pm 18,265$ & 0.0057 \\
\hline
\end{tabular}


pcak, and total CL parameters of the more heavily infected group were significantly greater than the comparable values of the lightly infected group. The Fisher PLSD and Scheffe F-tests were also significant at the $95 \%$ level when the CL parameters were compared between groups.

\section{Correlation of $C L$ parameters with levels of infection in individuals}

Since groups differed with regard to average levels of infection, and the CL responses seemed to be related to the levels of infection, we asked whether infection intensities were directly correlated with magnitude of $\mathrm{CL}$ responses in individual oysters. Diagnostic data and CL values were available for each oyster, and these data were analyzed for individuals without consideration of the particular groups from which they were collected. Table IIb shows that there were significant differences between mean CL parameters in oysters with light, moderate, or heavy Perkinsus infections. However, further examination showed that these differences were significant (95\% level, Fisher PLSD and Scheffe F-test) when comparing light versus heavy or moderate versus heavy infections, but not when comparing light versus moderate. Significant CL response differences can apparently only be seen between oysters with heavy Perkinsus infections and those with less intense infections. Since none of the oysters in this study were totally Perkinsus-free, we do not yet know whether uninfected oysters can be differentiated from lightly or moderately infected individuals based on their $\mathrm{CL}$ responsiveness.

When their relative contributions to the observed variation (induction) of CL parameters were analyzed (data in Tables Ila and b compared), the effects were clearly more associated with the levels of infection than with the group. Moreover, there were no significant interactions between individual and group infection level effects ( $P$ $>0.2$ for background, peak, and total CL).

\section{Total hemocyte counts in Perkinsus-infected oysters}

During the preparation of cells from batch 1 for CL assays, we noticed that the hemolymph from the heavily infected group sometimes seemed more turbid than that from the lightly infected group. This was tentatively ascribed to the presence of elevated numbers of circulating hemocytes; therefore, hemocyte counts were carried out on the second batch $(n=36)$. The total hemocyte counts in the second group of oysters (the more heavily infected group of Mobjack Bay transplants) were not significantly higher than those recorded for the lightly infected group (Table IIIa). But if the hemocyte data were grouped according to diagnostic scores of individual oysters (Table IIIb), the correlation between heavy intensity of infection and hemocyte numbers was noticeable, and the differences
Table III

Effects of Perkinsus marinus infection on total hemocyte count (THC) in Crassostrea virginica

a: Hemocyte numbers in lightly and heavily infected groups, as defined in Table I.

\begin{tabular}{ccc}
$\begin{array}{c}\text { Total hemocyte count } \times 10^{6} / \mathrm{ml}, \\
\text { mean } \pm \text { SEM }\end{array}$ & \\
$\begin{array}{c}\text { Group 1 } \\
\text { Lightly infected } \\
(\mathrm{n}=18)\end{array}$ & $\begin{array}{c}\text { Group 2 } \\
\text { Heavily infected } \\
(\mathrm{n}=18)\end{array}$ & $\begin{array}{c}P \text { value } \\
(\text { In }[1+\mathrm{X}] \text { transformed data, } \\
\text { F-test, two factor ANOVA })\end{array}$ \\
\hline $2.78 \pm 0.66$ & $4.15 \pm 0.65$ & 0.267 \\
\hline
\end{tabular}

b: Hemocyte numbers in individual oysters with known intensities of infection.

\begin{tabular}{|c|c|c|c|}
\hline \multicolumn{3}{|c|}{ Levels of infection } & \multirow{2}{*}{$\begin{array}{c}P \text { value } \\
\text { (calculated } \\
\text { as above) }\end{array}$} \\
\hline $\begin{array}{c}\text { Light } \\
(n=20)\end{array}$ & $\begin{array}{c}\text { Moderate } \\
(n=6)\end{array}$ & $\begin{array}{c}\text { Heavy } \\
(n=10)\end{array}$ & \\
\hline
\end{tabular}

$\mathrm{THC} \times 10^{6}$

$\begin{array}{lllll}(\text { mean } \pm \text { SEM }) & 2.52 \pm 0.47 & 2.95 \pm 0.54 & 5.68 \pm 1.15 & 0.002\end{array}$

between these groups were significant. Post hoc tests were also run to determine the significance of the differences observed between cell counts from oysters with different Perkinsus diagnostic scores. These results showed that significant differences (at the 95\% level, Fisher PLSD test) were encountered when comparing light versus heavy and moderate versus heavy, but not light and moderate. This was reminiscent of the findings when chemiluminescence data were compared according to these classifications.

\section{Discussion}

The method of transferring groups of oysters into Mobjack Bay at different times successfully produced populations with significantly different average levels of Perkinsus infection. However, at the times of sampling, no oysters were obtained that were entirely free of the sporozoan parasite. In an attempt to understand the status of the oysters' internal defense mechanisms during the course of the infection, the chemiluminescence (CL) response of hemocytes withdrawn from these oysters was determined. We knew that reactive oxygen intermediates (ROIs) produced by hemocytes were probably important to antimicrobial defense and that luminol-augmented $\mathrm{CL}$ is a sensitive method of ROI quantitation. Therefore, we predicted that decreased CL might be associated with Perkinsus infection, either as a result of the disease, or as a component of decreased resistance to the disease. Indeed, there is evidence that such is the case for certain other infections in bivalves. For example, the parasite Bonamia 
ostreae failed to stimulate $\mathrm{CL}$ production after ingestion by Ostrea edulis hemocytes (Hervio et al., 1989; Bachère et al., 1991b) and similar inhibition of CL followed phagocytosis of Rickettsiales-like organisms by the cells of Pecten maximus (LcGall et al., 1991). But the data reported here show that established Perkinsus infections apparently have the opposite effect: the hemocytes produce large amounts of ROIs, both at rest and after phagocytic stimulation.

The experimental groups varied with regard to residence time in Mobjack Bay (length of exposure to elevated salinity and to any environmental contaminants that might be present), as well as with regard to average level of infection. Although the water chemistry at the Mobjack Bay site was not analyzed, the area is considered to be relatively clean. Furthermore, exposure of bivalves to environmental pollutants can result in hemocyte $\mathrm{CL}$ suppression (Larson et al., 1989; Fisher et al., 1990; Anderson et al., 1992a, b), but rarely causes enhancement. Preliminary studies in this laboratory have failed to produce ROI modulation in hemocytes after salinity changes greater than that ( $8-20 \mathrm{ppt})$ experienced by the oysters in this study. Furthermore, since this salinity shock occurred a minimum of seven weeks before the oysters were collected; the animals probably had ample time to recover from this physiological stress. Therefore, the differences in $\mathrm{CL}$ responses observed between the groups are probably due to differences in Perkinsus infection intensities.

The relationship between infection and $\mathrm{CL}$ activity was further clarified when considered for individually diagnosed animals without regard to experimental group designations. Statistical analysis of the data showed that both resting and induced CL parameters in oysters with heavy infections were elevated compared to oysters with light or moderate infections. Clcarly, as the disease progressed, the circulating hemocytes produced greater amounts of ROIs and developed an increased capacity for ROI release upon phagocytic stimulation. In short, these cells appear to be activated, perhaps as a result of endocytosis of the Perkinsus organism itself; the sporozoan may be resistant to intracellular destruction and appears to be disseminated within the host via transport in hemocytes.

Although the mechanism of increased CL responsiveness of hemocytes from Perkinsus-infected oysters is not known, the phenomenon seems to be established. Preliminary results reported here also indicate that the total hemocyte count per $\mathrm{ml}$ hemolymph is higher in oysters with heavy infections. These two factors could work together to generate oxidant loads that could produce various forms of inflammatory cell damage in oysters during the later stages of infection, and play a role in the pathogenesis of the disease.

\section{Acknowledgments}

Expert technical assistance was provided by Laurie $M$. Mora, Lisa L. Brubacher, and Juanita Walker. This study was funded in part by NOAA Grant NA16FL0400-01.

\section{Literature Cited}

Adema, C. M., E. C. van Deutekom-Mulder, W. P. W. van der Knaap, E. A. Meuleman, and T. Sminia. 1991a. Generation of oxygen radicals in hemocytes of the snail Lymnaea stagnalis in relation to the rate of phagocytosis. Dov Comn Immunol. 15: 17-26.

Adema, C. M., W. P. W. van der Knaap, and T. Sminia. 1991 b. Molluscan hemocyte-mediated cytotoxicity: the role of reactive oxygen intermediates. Rev. Aquatic Sci. 4: 201-223.

Anderson, R. S., L. M. Mora, and S. A. Thomson. 1992a. Exposure of oyster macrophages to particulate brass suppresses luminol-augmented chemiluminescence. Toxicologist 12: 391.

Anderson, R. S., L. M. Oliver, and D. Jacobs. 1992b. Immunotoxicity of cadmium for the eastern oyster (Crassostrea virginica [Gmelin, 1791]): effects on hemocyte chemiluminescence. J. Shellfish Res. 11: 29-33.

Babior, B. M. 1984. Oxidants from phagocytes: agents of defense and destruction. Blood 64: 959-966.

Babior, B. M., J. T. Curnutte, and N. Okamura. 1988. The respiratory burst oxidase of the human neutrophil. Pp. 43-48 in Oxygen Radicals and Tissue Injury, B. Halliwell, ed. Fed. Amer. Soc. Exp. Biol. (for the Upjohn Company), Bethesda, MD.

Bachère, E., D. Hervio, and E. Mialhe. 1991a. Luminol-dependent chemiluminescence by hemocytes of two marine bivalves, Ostrea edulis and Crassostrea gigas. Dis. Aquat. Org. 11: 173-180.

Bachère, E., V. Boulo, P. Godin, L. Goggin, D. Hervio, G. LeGall, A. Morvan, and E. Mialhe. $1991 \mathrm{~b}$. In vitro chemiluminescence studies of marine bivalve defence mechanisms and responses against specific pathogens. Dev. Comp. Immunol. 15: S102.

Badwey, J. A., and M. L. Karnovsky. 1980. Active oxygen species and the functions of phagocytic leukocytes. Ann. Rev. Biochem. 49:695726.

Cochrane, C. G., I. U. Schraufstätter, P. Hyslop, and J. Jackson. 1988. Cellular and biochemical events in oxygen injury. Pp. 125-136 in Oxy-Radicals in Molecular Biology and Pathology, P. A. Cerutti, J. Fridovich and J. M. McCord, eds. Alan R. Liss, Inc., NY.

Cerutti, P. A., I. Fridovich, and J. M. McCord, eds. 1988. Oxy-Radicals in Molecular Biology and Patholngy. Alan R. Liss, Inc., N. Y.

DeChatelet, L. R., G. D. Long, P. S. Shirley, D. A. Bass, M. J. Thomas, F. W. Henderson, and M. S. Cohen. 1982. Mechanisms of the luminol-dependent chemiluminescence of human neutrophils. $\boldsymbol{T}$. Tmminol. 129: 1589-1593.

DiGiulio, R. T., P. C. Washburn, R. J. Wenning, G. W. Winston, and C. S. Jewell. 1989. Biochemical responses in aquatic animals: a review of determinants of oxidative stress. Environ. Toxicol. Chem. 8: 1103-1123.

Dikkeboom, R., J. M. G. H. Tijnagel, E. C. Mulder, and W. P. W. van der Knaap. 1987. Haemocytes of the pond snail Lymnaea stagnalis generate reactive forms of oxygen. J. Invertebr. Pathol. 49: 321-331.

Dikkeboom, R., W. P. W. van der Knaap, W. van den Bovenkamp, J. M. G. H. Tijnagel, and C. J. Bayne. 1988. The production of toxic oxygen metabolites by haemocytes of different snail species. Dev. Comp. Immunol. 12: 509-520.

Fantone, J. C. and P. A. Ward. 1982. Role of oxygen derived free radicals and metabolites in leukocyte-dependent inflammatory reactions. Am. J. Pathol. 107: 297-418.

Fisher, W. S., A. Wishkovsky, and F.-L. E. Chu. 1990. Effects of tributyltin on defense-related activities of oyster hemocytes. Arch. Environ. Contam. Toxicol. 19: 354-360. 
Halliwell, B., ed. 1988. Oxygen Radicals and Tissue Injury. Federation of American Societies for Experimental Biology, Bethesda, MD.

Hervio, D., E. Bachère, E. Mialhe, and H. Grizel. 1989. Chemiluminescent responses of Ostrea edulis and Crassostrea gigas to Bonamia ostrea (Ascetospora). Dev. Comp. Immunol. 13: 449.

Kako, K. J. 1987. Free radical effects on membrane protein in myocardial ischemia/reperfusion injury. $L \mathrm{MOL}$ Coll Cardiol. 19: 209 212.

Klebanoff, S. J. 1982. Oxygen-dependent cytotoxic mechanisms of phagocytes. Pp. 111-162 in Advances in Host Defense Mechanisms, Vol l, J. I. Gallin and A. S. Fauci, eds. Raven Press, NY.

Larson, K. G., B. S. Roberson, and F. M. Hetrick. 1989. Effect of environmental pollutants on the chemiluminescence of hemocytes from the American oyster Crassostrea virginica. Dis. Aquat. Org. 6: 131-136.

LeGall, G., E. Bachère, E. Mialhe, and H. Grizel. 1989. Zymosan and specific rickettsia activation of oxygen free-radicals in Pecten maximus hemocytes. Dev. Comp. Immunol. 13: 448.

LeGall, G., E. Bachère, and E. Miale. 1991. Chemiluminescence analysis of the activity of Pecten maximus hemocytes stimulated with zymosan and host-specific Rickettsiales-like organisms. Dis. Aquat. Org. 11: 181-186.

Livingstone, D. R., M. A. Kirchin, and A. Wiseman. 1989. Cytochrome P-450 and oxidative metabolism in molluscs. Xenobiotica 19: 10411062.

Livingstone, D. R., P. Garcia Martinez, X. Michel, J. F. Narbonne, S. O'Hara, D. Ribera, and G. W. Winston. 1990. Oxyradical pro- duction as a pollution-mediated mechanism of toxicity in the common mussel, Mytilus edulis L., and other molluscs. Funct. Ecol. 4: 415-424.

Nakamura, M., K. Mori, S. Inooka, and T. Nomara. 1985. In vitro production of hydrogen peroxide by the amoebocytes of the scallop, Patinopecten yessoensis (Jay). Dov Camp_Immunol. 9: 407-417.

Paynter, K. T., and E. M. Burreson. 1991. Effects of Perkinsus marinus infection in the Eastern oyster, Crassostrea virginica: II. Disease development and impact on growth rate at different salinities. $J$. Shellfish Res. 10: 425-431.

Pipe, R. K. 1992. Generation of reactive oxygen metabolites by the haemocytes of the mussel Mytilus edulis. 16: 111-122.

Ray, S. M. 1952. A culture technique for the diagnosis of infections with Dermocystidium marinum, Mackin, Owen and Collier, in oysters. Sence 116: 360-361.

Ray, S. M. 1966. A review of the culture method for detecting Dermocystidium marinum, with suggested modifications and precautions. Proc. Natl. Shellfish. Assoc. 54: 55-69.

Schlenk, D., P. Garcia Martinez, and D. R. Livingston. 1991. Studies on myeloperoxidase activity in the common mussel, Mytilus edulis L. Comp. Biochem. Physiol. 99C: 63-68.

Winston, G. W. 1991. Oxidants and antioxidants in aquatic animals. Comp. Biochem. Physiol. 100C: 173-176.

Winston, G. W., D. R. Livingstone, and F. Lips. 1990. Oxygen reduction metabolism by the digestive gland of the common marine mussel, Mytilus edulis L. J. Exp. Zool. 225: 296-308. 